\title{
REKONSTRUKSI DISKRESI DALAM PENYELENGGARAAN PEMERINTAHAN DAERAH SUATU KAJIAN UNDANG-UNDANG NOMOR 23 TAHUN 2014 TENTANG PEMERINTAHAN DAERAH
}

\author{
Muhammad Junaidi \\ Pasca Sarjana Magister Hukum Universitas Semarang \\ Email : institut.junaidi@gmail.com \\ Bambang Sadono \\ Pasca Sarjana Magister Hukum Universitas Semarang \\ Email : bambang.sadono@usm.ac.id
}

\begin{abstract}
Understanding the discretion or freedom act in countries such laws Indonesia is still have a dilemma due to the position of discretion position as a form of a policy still understood in partial not only the organizers State but also law enforcement. This is what then cause contradiction in the implementation of the State. This study was conducted by the ultimate goal is to provide clarity of the position of the implementation of the discretion in the implementation of the area. In addition to the research also want to analyze the extent of Law No. 23 Year 2014 on the Government the set in the discretion as one of the instrument of public policy. Through the juridical normative this research is expected to see and examines the extent apply the norm and asas that was supposed to be built in the construction of discretion against the implementation of the area. The approach is then do analysis in qualitative with the support of the data secondary consisting of the primary law, the legal tertiary and its laws secondary. The repositioning of discretion in the implementation of local government should certainly put discretion as a manifestation of the whole of the regional administration. The hierarchy of laws and regulations that often become obstacles element in understanding the implementation of discretion needs to be straightened out in accordance with the framework guidelines that the hierarchy of the law only as an element of the means of production in favor of justice, while through politics which is a forerunner to the creation of the essence of the law which aims to achieve fairness, certainty and expediency.
\end{abstract}

Keywords : Discretion, The Delivery and Local Governance

\begin{abstract}
Abstrak
Pemahaman diskresi atau kebebsan bertindak dalam negara hukum seperti Indonesia masih mengalami dilema akibat posisi dari kedudukan diskresi sebagai wujud pengambilan kebijakan masih dipahami secara parsial bukan hanya penyelenggara Negara akan tetapi juga penagak hukum. Hal inilah yang kemudian menimbulkan kontradiksi dalam penyelenggaraan Negara. Penelitian ini dilakukan dengan tujuan utamanya yaitu memberikan kejelasan kedudukan terhadap pelaksanaan diskresi dalam penyelenggaraan pemerintahan daerah. Selain itu penelitian ini juga ingin mengalisis sejauah mana Undang-Undang Nomor 23 Tahun 2014 tentang Pmerintah daerah mengatur keberlakuan diskresi sebagai salah satu instrument pembuatan kebijakan publik. Melalui pendekatan yuridis normative penelitian ini diharapkan melihat dan mengkaji sejauh mana keberlakuan norma dan asas yang seyogyanya perlu dibangun dalam konstruksi dasar diskresi terhadap penyelenggaraan pemerintahan daerah. Pendekatan tersebut kemudian dilakukan analisis secara kualitatif dengan
\end{abstract}


dukungan data secunder yang terdiri dari bahan hukum primer, bahan hukum tertier dan bahan hukum secunder. Reposisi diskresi dalam penyelenggaraan pemerintahan daerah tentunya harus menempatkan diskresi sebagai wujud utuh penyelenggaraan pemerintahan daerah. Hierarki perundang-undangan yang acapkali menjadi unsur hambatan dalam memahami implementasi diskresi perlu diluruskan sesuai dengan kerangka pedoman bahwa hierarki hukum hanya sebagai unsur alat produksi mendukung keadilan, sedangkan politiklah yang merupakan cikal bakal terciptanya esensi dari hukum yang bertujuan mencapai keadilan, kepastian dan kemanfaatan.

Kata kunci : Diskresi, Penyelenggaran dan Pemerintahan Daerah

\section{Pendahuluan}

Konsep rechtstaat bersumber dan rasio manusia, liberalistik individualistik, humanisme yang antroposentrik, pemisahan negara dan agama secara mutlak-ateisme dimungkinkan. Adapun unsure-unsur utama menurut F. J. Stahl terdapat 4 (empat) unsur dan negara hukum, yakni: (1) Adanya jaminan terhadap hak asasi manusia; (2) adanya pembagian kekuasaan; (3) pemerintah harusah berdasarkan peraturan-peraturan hukum; dan (4) adanya peradilan administrasi. Sementara menurut Scheltema unsur-unsurnya terdiri dan: (1) Kepastian Hukum; (2) Persamaan; (3) demokrasi dan; (4) pemerintahan yang melayani kepentingan umum. ${ }^{1}$

Bebrapa unsure di atas menjadi sangatlah menarik untuk diterapkan bagi sebauh Negara dalam memilih konsep Negara hukum ketimbang Negara kekuasaan. Konsep Negara kekuasaan dianggap belum mampu secara utuh dalam menjamin adanya Kepastian Hukum, Persamaan, demokrasi dan pemerintahan yang melayani kepentingan umum. Namuan yang dominasi yang dikedepankan adalah kepentingan pihak-pihak tertentu saja.
Dalam paham negara hukum yang demikian, harus dibuat jaminan bahwa hukum itu sendiri dibangun dan ditegakkan menurut prinsipprinsip demokrasi. Oleh karena itu, prinsip supremasi hukum dan kedaulatan huk um itu sendiri, pada dasarnya berasal dan kedaulatan rakyat. Oleh sebab itu, prinsip negara hukum hendakl ah dibangun dan dikembangkan menurut prinsip-prinsip demokrasi atau kedaulatan rakyat (demokratische recht7 sstaat). Hukum tidak boleh dibuat, ditetapkan, ditafsirk an, dan ditegakkan dengan tangan besi berdasarkan kekuasaan belaka (machtsstaat). Prinsip negara hukum tidak boleh ditegakkan dengan mengabaikan prinsipp rinsip demokrasi yang diatur dalam Undang-Undang Dasar. Oleh karena itu, perlu ditegaskan pula bahwa kedaulatan berada di tangan rakyat yang diberlakukan menurut Undang-Undang Dasar (constitutional democr acy) yang diimbangi dengan penegasan bahwa negara Indonesia adalah negara hukum yang berkedaulatan rakyat atau demokratis (democratische rechtsscaat). ${ }^{2}$

Sebutan lainnya untuk negara hukum yang berdasarkan kedaulatan hukum adalah "rule of law" menurut paham Dicey. Unsur ari rule of law adalah:

Sirajuddin dan Winardi, Hukum Tata Negara Indonesia, Malang: Setara Press (Kelompok Instras Publising), 2015, hlm. 25

2 Ni'matul Huda, Hukum Tata Negara Indonesia, Jakarta: Raja Grafindo Persada, 2015, hlm. 88-89 
a. Equality before the law, artinya setiap manusia mempunyai kedudukan hukum yang sama dan mendapatkan perlakuan yang sama

b. Supremacy of law, artinya kekuasaan tertinggi terletak pada hukum.

c. Hak-hak asasi manusia tidak bersumber pada undang-undang dasar. Ini adalah pengaruh daripada ajaran John Locke yang berpendapat bahwa pemerintah harus melindungi hak-hak asasi rakyat, dan karena itu hak-hak asasi itu dicantumkan dalam undang-undang dasar. ${ }^{3}$

Meskipun negaa hukum melihat dalam perspektif kekuasaan Negara yang melihat pada norma-norma kekuasaan rakyat, akan tetapi tetap dalam hal ini Negara memiliki kekuasaan penuh untuk menjalankan kemampuan dan keamauannya diluar batas apa yang menjadi rambu-rambu negara hukum. Hal inilah yang seringkali disebut dengan istilah kekuasaan politik.

Oleh Miriam Budiardjo, kekuasaan politik diartikan sebagi kemampuan untuk mempengaruhi kebijaksanaan umum (pemeritah) baik terbentuknya maupun akibat-akibatnya, sesuai dengan tujuantujuan pemegang kekuasaan sendiri. Misal, dalam sistem pemerintahan (sistem politik) yang berlaku di Indonesia sebagai saat ini. konvensi ketatanegaraan bahwa Presiden/Mandataris MPR menyiapkan bahan-bahan untuk ketatapanketetapan MPR mendatar Kalau bahan-bahan tersebut sebagai rancangan ketetapan MPR kemudian oleh MPR dijadikan ketetapannya, maka
Presiden/Mand ataris MPR telah mempengaruhi kebijaksanaan umum (kebijaksanaan atau ketetapan MPR) baik terbentuknya ketetapanketetapan MPR tersebut maupun akibat-akibatnya, dan tentu sesuai dengan keinginan Presiden sebagai pemegang kekuasaan pemerintahan. ${ }^{4}$

Kistilah kekuasaan politik disini bukan hanya dimiliki oleh presiden, akan tetapi juga unsure penyelenggara pemerintahan di bawahnya yang telah diberikan kewenangan oleh undang-undng untuk menyelenggarakan system pemerintahan nasional. Baik secara umum dan khsusus sebagaimana pemerintahan daerah yang menyelenggarakan pemerintahan daerah berdasarkan asasa otonomi dan tugas pembantuan.

Dalam konteks negara kesatuan penerapan asas sentralisasi dan desentralisasi dalam organisasi negara bangsa tidak bersifat dikotomis melainkan kontinum. Artinya pemerintah pusat tidak mungkin menyelenggarakan semua urusan pemerintahan ditangannya secara sentralisasi atau sebaliknya pemerintah daerah sepenuhnya menyelenggarakan semua urusan pemerintahan yang diserahkan. Yang bisa dilakukan adalah, selalu terdapat sejumlah urusan pemerintahan yang sepenuhnya diselenggarakan secara sentralisasi beserta penghalusannya, dekonsentrasi. Tidak pernah terdapat suatu urusan pemerintahan apapun yang diselenggarakan sepenuhnya secara desentralisasi. Urusan pemerintah yang menyangkut kepentingan dan kelangsungan hidup berbangsa dan bernegara lazimnya diselenggarakan secara sentralisasi dan 
dekonsetrasi sedangkan urusan yang mengandung dan menyangkut kepentingan masyarakat setempat diselenggarakan secara desentralisasi. ${ }^{5}$

Salah satu bentuk kekuasaan politik yang dimaksud dalam hal ini adalah kekuasaan dalam menjalankan diskresi (kebebasan bertindak) dalam penyelenggaran negara oleh aparatur Negara. Bentuk diskresi atau kebebasan bertindak dianggap mampu memenuhi kebuntuan berhukum yang selalu tersandera dalam praktik formalitas.

Di negara-negara Eropa Kontinental, konsepsi negara hukum mengalami perkembangan yang cukup pesat, terutama perkembangan terhadap asas legalitas yang sem ula diartikan sebagai pemerintahan berdasarkan undangu ndang (wetmatigheid van bestuur) kemudian berkembang menjadi pemerintahan berdasarkan hukum (rechtmatigheid van bestuur). Terjadinya perkembangan konsepsi terse- but merupakan konsekuensi dan perkembangan konsepsi negara hukum materiil sehingga pemerintah diserahi tugas dan tanggung jawab yang semakin berat dan besar untuk meningkatkan kesejahteraan warganya. Namun, pemerint ah diberikan pula ruang gerak yang semakin longgar, yang cenderung melahirkan pemerintahan bebas (vrij bestuur) disertai ruang kebijaksanaan yang longgar berupa freies ermessen. ${ }^{6}$

Namun dalam pemikiran lain kebebasan bertindak ini yang sangat berpotensi bagi aparat pemerintah atau administrasi Negara untuk dapat melakukan kecurangan karena dengan adanya kewenangan ini aparat pemerintah dapat dengan sebebas-bebasnya atas inisiatifnya menciptakan kebijakan dengan memanfaatkan kondisi-kondisi tertentu, hal ini yang sering terjadi pada kedua era tersebut diatas (orde lama dan Orde Baru). Padahal intinya kebebasan bertindak itu adalah untuk mensejahterakan masyarakat, oleh sebab itu di era reformasi ini diharapkan benar-benar kewenangan dalam hal kebebasan bertindak (diskresi) dimanfaatkan untuk masyarakat. ${ }^{7}$

\section{Pembahasan}

Di negara-negara Eropa Kontinental, konsepsi negara hukum mengalami perkembangan yang cukup pesat, terutama perkembangan terhadap asas legalitas yang semula diartikan sebagai pemerintahan berdasarkan undangu ndang (wetmatigheid van bestuur) kemudian berkembang menjadi pemerintahan berdasarkan hukum (rechtmatigheid van bestuur). Terjadinya perkembangan konsepsi terse- but merupakan konsekuensi dan perkembangan konsepsi negara hukum materiil sehingga pemerintah diserahi tugas dan tanggung jawab yang semakin berat dan besar untuk meningkatkan kesejahteraan warganya. Namun, pemerint ah diberikan pula ruang gerak yang semakin longgar, yang cenderung melahirkan pemerintahan bebas (vrij bestuur) disertai ruang kebijaksanaan yang longgar berupa freies ermessen. ${ }^{8}$

Prinsip kebebasan bertindak yang demikian akan memungkinkan pelaksana pemerintah mampu menterjemahkan segala hal yang berkaitan dengan prinsip-prinsip dan nilai-

\footnotetext{
Sirajuddin dan Winardi, Op., Cit, hlm. 333

Ni'matul Huda, Op., Cit, hlm. 85

Azmi Fendri, Kebebasan Bertindak Pemerintah (Diskresi) Sebagai Perwujudan Nilai-Nilai Moral Dan Etika, Jurnal ilmiu hukum, Volume 4 No. 3 September 2014-Januari 2015, hlm 140

8 Ni'matul Huda, Loc., Cit.
} 
nilai norma yang ada dalam masyarakat untuk diaktualisasikan dalam kebijakan maupun pelayanan publik secara progresif. Freies ermessen diambil dalam bahasa jerman sesuai dengan kamus bahasa inggris diartikan sebagai diskresi. Diskresi sendiri diartikan sebagai kebebasan bertindak dari pejabat adminstrasi yang berwenang dan berwajib menurut pendapat sendiri. ${ }^{9}$

Di indonesia ketentuan etrkait diskresi subtansinya dituangkan dalam Undang-Undang Republik Indonesia Nomor 30 Tahun 2014 Tentang Administrasi Pemerintahan. Salah satu pertimbangan dikeluarkannya ketentuan tersebut adalah :

a. bahwa dalam penyelenggaraan pejabat rangka meningkatkan pemerintahan, pemerintahan badan dalam wewenang harus mengacu pada kualitas dan/atau menggunakan asas-asas umum pemerintahan yang baik dan berdasarkan ketentuan peraturan perundang-undangan;

b. bahwa untuk menyelesaikan permasalahan dalam penyelenggaraan pemerintahan, pengaturan mengenai administrasi pemerintahan diharapkan dapat menjadi solusi dalam memberikan pelindungan hukum, baik bagi warga masyarakat maupun pejabat pemerintahan;

c. bahwa untuk mewujudkan pemerintahan yang baik, khususnya bagi pejabat pemerintahan, undangundang tentang administrasi pemerintahan menjadi landasan hukum yang dibutuhkan guna mendasari keputusan dan/atau tindakan pejabat pemerintahan untuk memenuhi kebutuhan hukum masyarakat dalam penyelenggaraan pemerintahan;

Dalam pasal 1 ayat 9 Undang-Undang tentang administrasi pemerintahan dijabarkan bahwa diskresi adalah Keputusan dan/ atau Tindakan yang ditetapkan dan/atau dilakukan oleh Pejabat Pemerintahan untuk mengatasi persoalan konkret yang dihadapi dalam penyelenggaraan pemerintahan dalam hal peraturan perundangundangan yang memberikan pilihan, tidak mengatur, tidak lengkap atau tidak jelas, dan/ atau adanya stagnasi pemerintahan. Diskresi jika dipahami dalam makna filosofis berdasarkan pertimbangan dikeluarkan undang-undang administrasi pemerintaan dan definisinya dalam Undang-undang tersebut bukan hanya diartikan kebebasan subjektif. Kebebasan subjektif tidak dapat dipahami bisa menjadi bagian keutuhan suatau kebijakan mengingat bentuk kebebasan tersebut sangat syarat dengan pembuat keputusan.

Diskresi sama dengan suatu ajaran subjektifitas namun dibangun dalam kerangka yang jelas. Halini sangat memungkinkan sama dengan dengan ajaran Thomas Aquinas terkait undangundang atau hukum itu merupakan kesimpulan dari pada ratio manusia dan yang berbentuk kemauan. Maka, sesuai dengan pendapat Cicero, undangundang itu merupakan pokok pangkal dan pikirannya, dan yang merupakan perintah dan ratio untuk kepentingan umum. Dan cara Thomas Aquinas memberikan ajarannya tentang keadilan dan hukum, memperlihatkan bahwa ia telah mempersatukan ajaran-ajaran : Aristoteles, Stoa,

9 S Pramudji Artosudibjo, Hukum Administrasi Negara, Jakarta; Ghalia Indonesia, 1994, hlm. 82 
Romawi, dengan ajaran Augustinus tentang dasar kekuasaan yang bersifat teokratis. Hanya saja sekarang dikatakan olehnya bahwa sumber tertinggi daripada hukum adalah terletak pada kepribadian Tuhan. ${ }^{10}$

Kaitannya terhadap prinsip tersebut, maka adanya diskresi yang dijabarkan dalam undangundang harus berpedoman pada asas penyelenggaraan pemerintahan yang baik. Asas penyelenggaraan pemerintahan yang baik yaitu :

a. Kepastian Hukum

Yang dimaksud dengan "asas kepastian hukum" adalah asas dalam negara hukum yang mengutamakan landasan ketentuan peraturan perundang-undangan, kepatutan, keajegan, dan keadilan dalam setiap kebijakan penyelenggaraan pemerintahan.

b. Kemanfaatan

Yang dimaksud dengan "asas kemanfaatan" adalah manfaat yang harus diperhatikan secara seimbang antara: (1) kepentingan individu yang satu dengan kepentingan individu yang lain; (2) kepentingan individu dengan masyarakat; (3) kepentingan Warga Masyarakat dan masyarakat asing; (4) kepentingan kelompok masyarakat yang satu dan kepentingan kelompok masyarakat yang lain; (5) kepentingan pemerintah dengan Warga Masyarakat; (6) kepentingan generasi yang sekarang dan kepentingan generasi mendatang; (7) kepentingan manusia dan ekosistemnya; (8) kepentingan pria dan wanita.

c. Ketidak Berpihakan
Yang dimaksud dengan "asas ketidak berpihakan" adalah asas yang mewajibkan Badan dan/atau Pejabat Pemerintahan dalam menetapkan dan/atau melakukan Keputusan dan/atau Tindakan dengan mempertimbangkan kepentingan para pihak secara keseluruhan dan tidak diskriminatif.

d. Kecermatan

Yang dimaksud dengan "asas kecermatan" adalah asas yang mengandung arti bahwa suatu Keputusan dan/atau Tindakan harus didasarkan pada informasi dan dokumen yang lengkap untuk mendukung legalitas penetapan dan/atau pelaksanaan Keputusan dan/atau Tindakan sehingga Keputusan dan/atau Tindakan yang bersangkutan dipersiapkan dengan cermat sebelum Keputusan dan/atau Tindakan tersebut ditetapkan dan/atau dilakukan.

e. Tidak Menyalahgunakan Kewenangan

Yang dimaksud dengan "asas tidak menyalahgunakan kewenangan" adalah asas yang mewajibkan setiap Badan dan/atau Pejabat Pemerintahan tidak menggunakan kewenangannya untuk kepentingan pribadi atau kepentingan yang lain dan tidak sesuai dengan tujuan pemberian kewenangan tersebut, tidak melampaui, tidak menyalahgunakan, dan/atau tidak mencampuradukkan kewenangan.

f. Keterbukaan

Yang dimaksud dengan "asas keterbukaan" adalah asas yang melayani masyarakat untuk mendapatkan akses dan memperoleh inform-

10 Soehino, 1996, Ilmu Negara, Yogyakarta: Liberty, 1996, hlm. 62 
si yang benar, jujur, dan tidak diskriminatif dalam penyelenggaraan pemerintahan dengan tetap memperhatikan perlindungan atas hak asasi pribadi, golongan, dan rahasia negara.

g. kepentingan Umum

Yang dimaksud dengan "asas kepentingan umum" adalah asas yang mendahulukan kesejahteraan dan kemanfaatan umum dengan cara yang aspiratif, akomodatif, selektif, dan tidak diskriminatif.

h. Pelayanan Yang Baik

Yang dimaksud dengan "asas pelayanan yang baik" adalah asas yang memberikan pelayanan yang tepat waktu, prosedur dan biaya yang jelas, sesuai dengan standar pelayanan, dan ketentuan peraturan perundang-undangan.

Selain asas umum pemerintahan yang baik yang dijelaskan dalam ketentuan peraturan perundang-undangan di atas, juga terdapat pula asas asas lain yang dijelakan oleh undang-undang sebagai asas diluar asas-asas umum pemerintahan yang baik. Dalam hal ini yang dimaksud adalah asas umum pemerintahan yang baik yang bersumber dari putusan pengadilan negeri yang tidak dibanding, atau putusan pengadilan tinggi yang tidak dikasasi atau putusan Mahkamah Agung.

Doktrin diskresi yang sebenarnya juga dijabarkan dalam Undang-Undang pemerintahan daerah juga tidak terlepas dari subtansi ajaran negara konstitusional. Sifat otonom yang dijabarkan dalam Undang-Udang Dasar 1945 pasal 18 setidaktidaknya menjadi sinopsis karakteristik penyelenggaraan pemerintahan yang tidak bisa mengesampingkan nilai kebebasan penyelenggara pemerintahan secara sah untuk membentuk ruangruang kebijakan strategis sesuai dengan nilai-nilai kearifan dalam masayarakat lokal. Konsekwensi logis akar filosofis dalam wujdu diskresi pada penyelenggaraan daerah merupakan karakter pembangunan hukum nasional yang berintegrasi kepada tujuan dan orientasi bernegara.

Rambu-rambu tersebut kemudian diperkuat dengan adanya empat kaidah penuntun hukum yang harus dipedomani sebagai kaidah dalam politik atau pembangunan hukum, yaitu: Pertama, hukum nasional harus dapat menjaga integrasi (keutuhan) baik ideologis maupun wilayah teritorial sesuai dengan tujuan 'melindungi segenap bangsa dan seluruh tumpah darah Indonesia.' Harus dicegah munculnya produk hukum yang berpotensi memecah belah keutuhan bangsa dan negara Indonesia, termasuk hukum-hukum yang diskriminati berdasar ikatan-ikatan primordial. Kedua, hukum nasional harus dibangun secara demokratis dan nomokratis dalam arti harus mengundang partisipasi dan menyerap aspirasi masyarakat luas melalui prosedur-prosedur dan mekanisme yang fair, transparan, dan akuntabel. Harus dicegah munculnya produk hukum yang diproses secara licik, kucing-kucingan, dan transaksi di tempat gelap. Meskipun secara demokratis pembentukan hukum itu benar, tetapi jika salah secara nomokratis (prinsip hukum) maka hukum itu batal atau dapat dibatalkan oleh lembaga yudisial. Ketiga, hukum nasional harus ditujukan juga untuk menciptakan keadilan sosial dalam arti 
harus mampu memberi proteksi khusus terhadap golongan yang lemah dalam berhadapan dengan golongan yang kuat baik dan luar maupun dan dalam negeri sendiri. Tanpa proteksi khusus dan hukum golongan yang lemah pasti akan selalu kalah jika dilepaskan bersaing atau bertarung secara bebas dengan golongan yang kuat. Keempat, hukum harus menjamin kebebasan beragama dengan penuh toleransi antarpemeluk-pemeluknya. Tidak boleh da pengistimewaan perlakuan terhadap agama dan pemeluknya rianya karena didasarkan pada. besar dan kecilnya jumlah Demeluk. Perlakuan proporsional tentu saja diperbolehkan, tetapi pengistimewaan tidak diperbolehkan. Negara boleh riengatur kehidupan beragama sebatas pada menjaga ketertiban aar tidak terjadi konflik serta memfasilitasi agar setiap orang .apat melaksanakan ajaran agamanya dengan bebas tanpa menganggu atau diganggu oleh orang lain. Hukum agama tidak perlu diberlakukan oleh negara sebab pelaksanaan ajaran agama diserahkan kepada masing-masing pribadi pemeluknya, tetapi agar dapat mengatur pelaksanaannya oleh pemeluk masing masing untuk menjamin kebebasan dan menjaga ketertiban dalam pelaksanaannya tersebut. ${ }^{11}$

Adanya dikotomi perluasan penafsiran terhadap penyelenggaraan pemerintahan yang bermuatan diskresi nampak pada bagian pertimbangan Undang-Undang Nomor 23 tahun 2014 tentang Pemerintahan daerah yang secara tegas memberikan pertimbangan diantaranya sebagai berikut :

a. bahwa penyelenggaraan pemerintahan daerah diarahkan untuk mempercepat terwujudnya kesejahteraan masyarakat melalui peningkatan pelayanan, pemberdayaan, dan peran serta masyarakat, serta peningkatan daya saing daerah dengan memperhatikan prinsip demokrasi, pemerataan, keadilan, dan kekhasan suatu daerah dalam sistem Negara Kesatuan Republik Indonesi

b. bahwa efisiensi dan efektivitas penyelenggaraan pemerintahan daerah perlu ditingkatkan dengan lebih memperhatikan aspek-aspek hubungan antara Pemerintah Pusat dengan daerah dan antardaerah, potensi dan keanekaragaman daerah, serta peluang dan tantangan persaingan global dalam kesatuan sistem penyelenggaraan pemerintahan negara;

Jika dilakukan penelaaahan lebih jauh maka ruang diskresi dalam hal penyelenggaraan pemerintahan daerah sesuai dengan Undangundang Pemerintahan daerah, telah dibuka secara luas sesuai dengan ketentuan peraturan perundang-undangan yang berlaku. Hal ini tentunya sangat memberikan dampak positif bagi penyelenggaraan pemerintahan yang berlaku dinegara kesatuan republik Indonesia.

Dalam wawasan hukum yang berkembang dewasa ini, hukum oleh pemerintahnya atau pemimpinnya digunakan sebagai sarana dalam merencanakan dan mengorganisasikan struktur ekonomi dan sosial tersebut, dan ia hanya sekadar bagian dan struktur ideologis yang mengontrol realitas materi dan sarana produksi; ia ditentukan dan didefinisikan dalam kaitannya dengan fungsi

\footnotetext{
11 Mahfud MD, Konstitusi dan Hukum Dalam Kontroversi Isu, Jakarta: Raja Grafindo Persada, 2010, hlm 38-39
} 
politisnya. Bahwa seluruh cita hukum berkaitan dengan negara dan karena itu merupakan sarana dengan mana mereka yang mengawasi alat-alat produksi tetap mengawasi mereka yang dicabut hak miliknya. Dengan berpindahnya pemilikan alat-alat produksi ke tangan masyarakat, individu akan dilibatkan, seperti halnya negara dan hukum, yang dibenarkan hanya oleh kebutuhan dengan paksaan. ${ }^{12}$

Disini dapat dipahami bahwa unsur utama peneyelanggaraan negara tidaklah bisa diserahkan pada prinsip-prinsip peraturan perundangundangan yang berlaku. Unsur keberlakuan politik yang menjadi salahs atu wujud keberlakuan normanorma hukum juga menjadi pertimbangan prinsipil dalam penyelenggaraan hukum dan pemerintahan yang ada sesuai dengan Undang-Undang Nomoe 23 tahun 2014 tentang Pemerintahan Daerah.

Dalam penjelasan Undang-undang Nomor 23 tahun 2014 dinyatakan diantaranya sebagai berikut :

Berbeda dengan penyelenggaraan pemerintahan di pusat yang terdiri atas lembaga eksekutif, legislatif, dan yudikatif, penyelenggaraan Pemerintahan Daerah dilaksanakan oleh DPRD dan kepala daerah. DPRD dan kepala daerah berkedudukan sebagai unsur penyelenggara pemerintahan daerah yang diberi mandat rakyat untuk melaksanakan Urusan Pemerintahan yang diserahkan kepada Daerah. Dengan demikian maka DPRD dan kepala daerah berkedudukan sebagai mitra sejajar yang mempunyai fungsi yang berbeda. DPRD mempunyai fungsi pembentukan Perda, anggaran dan pengawasan, sedangkan kepala daerah melaksanakan fungsi pelaksanaan atas Perda dan kebijakan Daerah. Dalam mengatur dan mengurus Urusan Pemerintahan yang menjadi kewenangan Daerah tersebut, DPRD dan kepala daerah dibantu oleh Perangkat
Daerah. Sebagai konsekuensi posisi DPRD sebagai unsur penyelenggara Pemerintahan Daerah maka susunan, kedudukan, peran, hak, kewajiban, tugas, wewenang, dan fungsi DPRD tidak diatur dalam beberapa undang-undang namun cukup diatur dalam Undang-Undang ini secara keseluruhan guna memudahkan pengaturannya secara terintegrasi.

Sesuai dengan prinsip di atas, maka karakteristik penyelengaraaan pemerintahan daerah sesuai dengan Undang-Undang Nomor 23 tahun 2014 tentang Pemerintahan daerah tentunya tidak bisa dibatasi berdasarkan bentuk hierarki perundang-undangan. Nilai esensi dasar dalam penyelenggaraan pemerintahan daerah harus mewujudkan tatanan norma-norma subtansi yang pada gilirannya menjadi pedoman penyelenggara pemerintahan untuk menyelengarakan sistem dan tatanan pemerintahan yang bermartabat.

Kebutuhan rekonstruksi yang dipraktikkan dalam asas otonom merupakan bentuk perwujudan dari sebuah analogis bahwa posisi nilai tawar unsurunsur sosiologi hukum harus menjadi pertimbangan. Pertimbangan yang dimaksudkan disini adalah pertimbangan dalam memutuskan persoalanpersoalan yang rumit dan apabila acapkali didekatkan dengan pendekatan hukum, maka akan menjadi sumber kompleksitas permasalahan.

Paul Bohanan seorang ahli antropologi juga mempersoalkan perkaitan fungsional antara hukum dengan basis sosialnya. Bohanan memulai dengan memperhatikan perkaitan antara hukum dan kebiasaan. Kebiasaan adalah seperangkat norma- norma yang secara nyata dilakukan seharihari. Tiap lembaga di dalam masyarakat didukung

12 Zainal Asikin, Pengantar Tata Hukum Indonesia, Jakarta: Raja Grafindo Persada, 2013, hlm 84 
oleh kebiasaan. Menurut Bohanan ciri-ciri yang terdapat dalam definisi-definisi hukum dapat dijumpai semuanya dalam kebiasan. Bedanya hanya kebiasaan itu tetap berada dalam keadaan semula, sedangkan hukum diciptakan kembali secara lebih khusus oleh badan di dalam masyarakat ke dalam bentuk yang lebih khusus, lebih sempit dan lebih jelas. Dalam bentuknya yang demikian ini, kebiasan lalu dikatakan memiliki ciri hukum (legal character) sehingga menurut Bohanan hukum merupakan suatu perkembangan kembali (reinstitusionaljzat ion) dan kebiasaan Hukum adalah kebiasaan yang mengalami pelembagaan kembali untuk memenuhi tujuan yang lebih terarah dalam kerangka yang disebut hukum. Melalui pelembagaan kembali itu kebiasaan diolah secara khusus memperoleh bentuk yang dapat dikelola secara hukum. ${ }^{13}$

Disini dapat diberikan gambaran bahwa unsur diskresi penyelenggara negara sangatlah dibutuhkan yang tentunya tetap tidak melepaskan prinsip-prinsip nilai asas umum penyelenggaraan pemerintahan yang baik. Namun yang menjadi kendala adalah tafsir hierarki peraturan perundangundangan pada posisi lain telah memberikan konstruksi yang berbeda terhadap pelaksanaan penyelenggaraan pemerintahan yang baik dan benar.

Oleh karenanya sudah semestinya dalam menjalankan dan mendeskripsikan diskresi secara tepat, pendekatan hierarki harus diposisikan sebagai sarana memahami hukum, bukan sebagai pertimbangan terakhir sehingga menjadikan unsur diskresi lebih memiliki kecemderungan terhadap kesalahan atas perilaku yang dilakukan oleh penyelenggara negara.

\section{Kesimpulan}

Dalam pasal 1 ayat 9 Undang-Undang tentang administrasi pemerintahan dijabarkan bahwa diskresi adalah Keputusan dan/ atau Tindakan yang ditetapkan dan/atau dilakukan oleh Pejabat Pemerintahan untuk mengatasi persoalan konkret yang dihadapi dalam penyelenggaraan pemerintahan dalam hal peraturan perundangundangan yang memberikan pilihan, tidak mengatur, tidak lengkap atau tidak jelas, dan/ atau adanya stagnasi pemerintahan. Prinsip diskresi melalui kaidah yang ada tersebut tentunya juga menjadi esensi dalam Undang-Undang Nomor 23 tahun 2014 tentang Pemerintahan Daerah yang pada prinsipnya ditegaskan bahwa penyelenggaraan berdasarkan pada nilai-nilai otonom. Sifat otonom disini jelas memberikan konsekwensi bagi penyelanggara pemerintahan untuk mampu menterjemahkan pokok-pokok kandungan kebijakan yang sesuai dengan kepentingan masyarakat.

Reposisi diskresi dalam penyelenggaraan pemerintahan daerah tentunya harus menempatkan diskresi sebagai wujud utuh penyelenggaraan pemerintahan daerah. Hierarki perundangundangan yang acapkali menjadi unsur hambatan dalam memahami implementasi diskresi perlu diluruskan sesuai dengan kerangka pedoman bahwa hierarki hukum hanya sebagai unsur alat produksi mendukung keadilan, sedangkan politiklah yang merupakan cikal bakal terciptanya esensi dari

13 Suteki, Desain Hukum Di Ruang Sosial, Yogyakarta: Thafa Media, 2013, hlm 83-84 
214 Muhammad Junaidi \& Bambang Sadono, Rekonstruksi Diskresi Dalam...

hukum yang bertujuan mencapai keadilan,

kepastian dan kemanfaatan.

\section{DAFTAR PUSTAKA}

Buku-buku

Mahfud MD, Konstitusi dan Hukum Dalam Kontroversi Isu, Jakarta: Raja Grafindo Persada, 2010.

Moh Kusnardi dan Bintan R Saragih, Ilmu Negara, Jakarta: Gaya Media Pratama, 1994.

Ni'matul Huda, Hukum Tata Negara Indonesia, Jakarta: Raja Grafindo Persada, 2015

S Pramudji Artosudibjo, Hukum Administrasi Negara, Jakarta: Ghalia Indonesia, 1994.

Sirajuddin dan Winardi, Hukum Tata Negara Indonesia, Malang: Setara Press (Kelompok Instras Publising), 2015.
Soehino, IImu Negara, Yogyakarta, Liberty, 1996.

Suteki, Desain Hukum Di Ruang Sosial, Yogyakarta: Thafa Media, 2013.

Zainal Asikin, Pengantar Tata Hukum Indonesia, Jakarta: Raja Grafindo Persada, 2013.

Jurnal

Azmi Fendri, Kebebasan Bertindak Pemerintah (Diskresi) Sebagai Perwujudan Nilai-Nilai Moral Dan Etika, Jurnal IImu Hukum, Volume 4 NO. 3 September 2014-Januari 2015 